Mavi Atlas, 9(2)2021: 167-181

Makale Geliș | Received: 24.09.2021

Makale Kabul | Accepted: 18.10.2021

DOI: $10.18795 /$ gumusmaviatlas.1000529

\begin{abstract}
Osman TAŞKIN
Dr. Öğr. Üyesi | Asst. Prof.

Kilis 7 Aralı Üniversitesi, Fen Edebiyat Fakültesi, Tarih Bölümü, Kilis-TÜRKIYYE

Kilis 7 Aralik University, Faculty of Science and Literature, The History Department, Kilis-TURKEY

ORCID: 0000-0002-6193-7169

osman.taskin@kilis.edu.tr
\end{abstract}

\title{
Ekonomik ve Tipolojik Bir Tahlil: Kilis’te Gayrimüslimler (1846-1849)
}

$\ddot{\mathrm{O} z}$

Bu çalışma 1840'ların sonunda Kilis'te yaşayan gayrimüslim cemaatlerin ekonomik durumlarına, nüfus ve tipolojik yapılarına odaklanmıştır. Çalışmada1846-1849 yıllarına ait üç ayrı cizye defterlerinden elde edilen bilgiler çerçevesinde gayrimüslim cemaatlerin ekonomik durumları karşılaştırmalı olarak incelenmesi hedeflenmiştir. Dişardan gelen gayrimüslimlerden yola çıkarak Kilis'in bu tarihlerde hangi kazalarla ticari veya sosyal ilişki içerisinde olduğu ortaya konulmaya çalışılmıştır. Şehirde hangi gayrimüslim cemaatlerin yaşadığı ve bunların ekonomik yaşam düzeyleri arasında belirgin bir fark olup olmadı̆̆1, varsa hangi cemaatin daha yüksek bir gelir seviyesine sahip olduğu tespit edilmeye gayret gösterilmiştir. Bulunduğu coğrafyanın kavşağında yer alan Kilis’e hangi güzergâhtan daha fazla gayrimüslimin geldiği sorusuna yanıt aramak da araştırmanın hedeflerinden birisini oluşturmaktadır. Bununla birlikte gayrimüslimlerin yaşları ve fiziksel özellikleri çerçevesinde elde edilecek veriler sayesinde hangi fiziksel özelliklere sahip oldukları incelenecektir. Kilis'te yaşayan vergi mükellefi gayrimüslimler çevre şehirlerde yaşayan aynı kategorideki gayrimüslimlerle yaş ortalamaları, genç ve yaşlı nüfus açısından karşılaştırılarak belirgin farklar ele alınacaktır. Tipolojik anlamda Kilis'te yaşayan gayrimüslimlerin belirgin özellikleri tespit edilerek karşılaştırmalı bir şekilde incelenecektir. Gayrimüslimlerde fiziksel görünümü etkileyen sakal veya bıyık bırakma âdetinin hangi seviyede olduğu belirlenecek ve bıyık veya sakal bırakma tercihlerinin yaşın ilerlemesiyle bir bağlantısının olup olmadığı sorusuna yanıt aranacaktır. Ayrıca gayrimüslimlerin boy seviyeleri incelenerek yoğun olarak hangi boy seviyesine sahip oldukları tespit edilmeye çalışılacaktır.

Anahtar Kelimeler: Kilis, Gayrimüslim Cemaatler, Cizye, Ekonomik ve Sosyal Tarih, Ermeni

\section{An Economic and Typological Analysis: Non-Muslim Communities in Kilis (1846-1849)}

\begin{abstract}
This study focused on the economic conditions, population and typological structures of the non-Muslim communities living in Kilis in the late 1840s. In this study, it is aimed to comparatively examine the economic conditions of non-Muslim communities within the framework of the information obtained from three separate jizya registers belonging to the years 1846-1849. Based on the non-Muslims coming from outside, it has been strived to reveal with which districts Kilis was in commercial or social relations during these dates. It has been tried to determine which non-Muslim communities live in the city and whether there is a significant difference between their economic life levels, and if so, which community has a higher income level. One of the objectives of the research is to seek an answer to the question based on from which route more non-Muslims come to Kilis, which is located at the crossroads of its geography. In addition, the physical characteristics of non-Muslims will be examined, thanks to the data to be obtained within the framework of their ages and physical characteristics. The significant differences will be discussed by comparing the taxpayer non-Muslims living in Kilis with the non-Muslims living in the surrounding cities in terms of average age, young and old population. In the typological sense, the distinctive features of the non-Muslims living in Kilis will be determined, and examined in a comparative way. The level of beard or mustache growth, which affects the physical appearance of non-Muslims, will be determined and an answer will be sought to the question of whether there is a relationship between mustache or beard growth preferences and age. Furthermore, the height levels of non-Muslims will be examined, and it will be tried to determine which height level they have intensively.
\end{abstract}

Keywords: Kilis, Non-Muslim Communities, Jizya, Economic and Social History, Armenian. 


\section{Giriş $^{1}$}

Birçok araştırma gayrimüslimlerin ticari sahada daha çok yer almalarını, devletin uygulamış olduğu sistem sayesinde elde ettiklerini ortaya koymaktadır. Bu hususta gayrimüslimlerin ekonomik durumlarını ortaya koyan nüfus defterleri ve cizye defterleri önemli bir yer tutmakta ve demografi çalışmalarda birbirini tamamlamaktadır (Çoruh, 2020, s. 78). Ancak genellemeler bütün coğrafyalarda yaşayan gayrimüslimleri kapsayacağı için sağlıklı ve bilimsel bir yaklaşım olmayacaktır. Bu noktada bölgesel veya şehir merkezli karşılaştırmalı çalışmalar önemli hale gelmektedir. Bunların tamamlanmasından sonra çalışmaların toparlanmasıyla belki daha geniş çaplı değerlendirme imkânı elde edilmiş olunacaktır. Bu çerçevede Kilis ve çevresindeki şehirler, araştırmalara konu olacak önemli yerler arasında yer almaktadır. Bu çalışmanın genel hedefi Kilis ve yakın çevresiyle ilgili çalışmalara katkı sunması yanında daha özelde Kilis'te yaşayan ve çevre şehirlerden geçici olarak gelen gayrimüslimlerin ekonomik durumları ve fiziksel özellikleriyle ilgili ekonomik ve tipolojik bir tahlil yapmaktır. Bu bilgiler üç ayrı cizye defteri kullanılacaktır. Çalışma, 1846 ve 1849 yıllarında Kilis'te yaşayan gayrimüslimlerin nüfusu, ekonomik durumları ve çevre şehirler ile olan ticari ilişkilerini ortaya koymaktır. Ayrıca yapılan çalışmalardan yararlanarak yakın kaza ve sancak merkezlerinde yaşayan gayrimüslimlerle karşılaştırmalar yapıp Kilisli gayrimüslimlerin ekonomik seviyeleri daha anlaşılır hale getirilmeye çalışılmıştır. Ekonomik tespitlerin yansıra fiziksel tanımlamaların değerlendirilmesi ile antropolojik araştırmalara kaynaklık edecek verilerin ortaya konması da hedeflenmiştir. Çalışmanın temel kaynakları Başkanlık Osmanlı Arşivinde bulunan ve üzerinde ayrıntılı çalışma yapılmamıs Maliye Nezareti Varidat Muhasebesi Cizye Defterlerinden (BOA.ML.VRD.CMH.d.) 652, 933 ve 1493 numaralı defterlerdir. ${ }^{2}$ Konu Kilis'in şehirleşme sürecine ve nüfus gelişimine genel hatlarıyla değindikten sonra gayrimüslimlerin ekonomik durumları ve tipolojik özelliklerinin tahlil edilmesi suretiyle ele alınmıştır.

Osmanlı Devleti'nde devlet otoriteleri ile gayrimüslim toplulukları arasindaki düzenlemeleri tanımlamak için kullanılan "millet sistemi" sayesinde çok yapılı, farklı din ve etnik yapıya sahip topluluklar Osmanlı yaşamına dâhil edilmiştir. Fatih Sultan Mehmet dönemi ile şekillenen bu oluşum Tanzimat Dönemi'nde değişmiştir. İslami zimmet kavramının ve Roma cemaatler sisteminin birleşiminden meydana gelen bu kurumsal yapı içerisinde önemli bir tolerans barındırmakla birlikte temelde idari, hukuki ve siyasi bir organizasyon olarak tarif edilmektedir (Braude, 1999, s. 245; Adıyeke, 2014, s.345). Bu yap1 1856 Islahat Fermanı ile birlikte önemli ölçüde ortadan kaldırılıncaya kadar kurumsallaşmasını Osmanlı döneminde kazanmıştır. Kendi topraklarında başka din mensuplarına hayat hakkı tanıyan İslam hukuku tarih boyunca bu anlayışını değiştirmeden Osmanlı Devleti'ne kadar devam ettirmiştir. Osmanlı Devleti de kuruluşundan itibaren gayrimüslimleri İslam hukukunun zimmet ve eman kurumları çerçevesinde yönetmiştir. Zimmet hukuku çerçevesinde din ve vicdan hürriyeti bakımından istikrarlı bir seyir takip etmiştir. Yine devlet İslam hukukuna göre güvenliğinin karşıllğı olarak cizye vergisi almıştır (Kenanoğlu, 2013, s. 438, 440; Küçük, 1999, s. 208; Çoruh, 2020, s. 78; Özel, 1996, s. 418). Osmanlı Devleti'nde XVI. yüzyıla kadar cizye vergisi yerine haraç kelimesi kullanılmışsa da cizye veya "cizye-i şer'i" kavramı yaygınlık kazanmıștır. Arazi haracından ayırt edebilmek için "baş haracı" tabiri kullanılmıştır. (İnalcık, 1993, s. 45) Haraç vergisine "cizyetü’l- arz", cizye vergisine de "haracu'r- ru'us da denilmiştir (Ercan, 1991, s. 372). Gayrimüslimlerden zimmet statüsü kazanan kişinin devlete karşı sorumluluğu sadece cizye vergisi olup bu vergi hâkimiyetin sembolü

\footnotetext{
1 Bu makale 07/08/09 Eylül 2021 tarihinde İstanbul'da Rimar Akademi, Mardin Artuklu Üniversitesi ve Kudüs Üniversitesi işbirliğiyle gerçekleştirilen II. Uluslararası Tarih Araştırmaları Kongresi’nde sunulmuş sözlü bildirinin genișletilmiș hâlidir.

21260 (1845) tarihli 408 numaralı defter defterde alâ 10, evsât sınıfından 170 kayıt yapıldıktan sonra edna sinıfina ait kayıtlar olmadığı gibi defterin sonunda toplamları veren özet ve mühür kısmı yoktur. Bir yıl sonra tutulan 652 nolu defterdeki veriler kullanılmıștır.
} 
olarak alınıp kişinin can, mal ve namus güvenliğini sağlama karşılığı sayılmıştır (Kocaoğlu, 2018, s. 285).

Cizye vergisi gayrimüslimlerin (zimmî) gelir durumlarına göre yüksek orta ve düşük olmak üzere alâ, evsât, ednâ şeklinde üç sınıfa ayrılmışlardır. İslamiyet’in ilk dönemlerinde 48, 24, 12 dirhem şeklinde üç sinıfta belirlendiği için Osmanlı Devleti'nde de buna uygun olarak belirlenmiştir. Ancak paranın standardındaki değişmeler bu kat sayının değişmesini zorunlu hale getirmiş sadece alâ, evsât ve ednâ şeklindeki sınıflamaya uyulmuş alınan cizye miktarları zaman içerinde değiştirilmiştir (Ercan 1991, p. 373; Konan, 2015, s. 183). Bu çalışmada kullandığımız cizye defterlerinde bu sinıflandırmaya tabi olarak alâ 60, evsât 30, ednâ 15 kuruş şeklinde toplanmış ve kayda geçirilmiştir. Cizye vergisi, İslam hukukunun gereği olduğu için toplanmasına ve harcanmasına dikkat edilmiştir. Genelde devletin görevli memurları tarafindan toplanmıştır. Ancak çoğu zaman cizyedâr denilen mültezimler toplamıştır. Cizye vergisinin toplanmasından sonra her mahalle ve köye "temessük" veya "tezkire" denilen bir resmi belge verilirdi. Zamanla cizye toplanmasında yaşanan yolsuzlukların önüne geçmek için cizyesini ödeyene cizye kâğıdı verilmeye başlanmıştır. Muhasebe kalemi vergi toplanacağı zaman her bölgenin ne kadar cizye kâğıdı varsa bir bohçaya koyar mültezime teslim ederdi. Vergi toplayan kişi vergisini aldığı gayrimüslime cizye kâğıdını teslim ederdi (Ercan, 1991, s. 374). Böylece bir kişi başka bir yere gittiğinde vergi kağıdını göstererek vergisini ödediğini belgeleyerek tekrar vergi vermek durumunda kalmazdı.

Islahat Fermanı'yla "millet sistemi” yeniden ele alınmış gayrimüslimlere daha geniş ayrıcalıklar tanınmıştır. 1861 yılında Rum Patrikliği, 1863 yılında Ermeni Patrikliği, 1865 yılında Hahamhane Nizamnamesi yayınlanmıştır. Ardından Vilayet Nizamnamesi ile zimmîlere vilayet meclislerinde temsil hakkı tanınmıştır. 1869 senesinde ise Tabiiyet-i Osmaniye Kanunnamesinin 9. maddesi ile Osmanlı Devleti'nde zimmîlik statüsü kaldırılmış Osmanlı vatandaşlı̆̆ı kavramı getirilmiştir. Böylece İslam hukuku çerçevesinde din temeline dayanan vatandaşlık kavramı yerine modern uyrukluk kavramı getirilmiştir. 1876 anayasasında "Osmanlı tabiiyetinde bulunan herkes hangi din ve mezhepten olursa olsun istisnasız "Osmanlı tabir olunur" maddesiyle Müslüman ve gayrimüslim vatandaş ayrımı kaldırılmıştır (Konan, 2015, s. 187).

\section{Şehrin Gelişimi}

Kilis yerleşimi itibariyle Gaziantep platosunun güneybatısında Suriye sınırındadır (Akdemir \& İncili, 2013, s. 80). İbrahim Konyalı İngiltere müzesindeki çivi yazılı kitabeye göre Kilis'in en az 2800-3000 yll önce var olduğunu ifade etmektedir (Konyalı, 1968, s. 31,32). Kilis'in Oylum köyünde bulunan Oylum höyüğü üç bin yılllk bir geçmişe sahip olduğu yapılan arkeolojik kazılarla da ortaya konulmaktadır (Kesici, 2011, s. 247). Hicri VII. yüzy1lda Kilize isminin Ebu’lfida (İbn-i Kesir) tarihinde yazdığı ifade edilmektedir (Ercivan, 2010, s. 25). 1073’te Haçlıların Anadolu'ya gelişi sırasında Kalçıs, daha sonraları Gizle (Kilize) olarak anılmış ve nihayetinde Kilis adını almış olduğu ifade edilir (Ercivan, 2010, s. 35). Ayrıca Ravanda Kalesi'nin Haçlılar tarafindan 1097 yılında Türklerin elinden alındığına bakılırsa kasabada bu tarihten önce Türk hâkimiyetinin gerçekleştiği anlaşılmaktadır (Demirkent, 1992, s. 374). Kilis’in bugünkü yerinde ne zaman kurulduğu hususu net olarak tarihlendirilemese de Timur'un Azez kasabasinı tahrip etmesinden sonra göçenlerle şehrin genişlemiş olduğu kaydedilmektedir (Darkot, 1977, s. 806; Halep Salnamesi 1302/1885, s. 166; Kilisli Kadri, 1932, s. 18). Kilis’in asıl şehirleşme süreci bölgenin fethinden sonra 1519'da başlamıştır. O dönemde şehir yapısının temel yapıları olan hamam-1 atik, boyacı dükkânı, sipahi pazarı, Ulu Cami ve Pirlioğlu veya Alacacı Cami gibi yapılar mevcuttu (Ercivan, 2010, s. 35). XVI. yüzyıl sonunda beş altı mahalle 600 civarında hanenin bulunduğu bir şehir olmuştur. Karakadı Cami ile Sabah pazarı çevresinde şekillenen şehir merkezi Büyükkütah, İnnaplikütah, Tabakhane, Hakverdi ve Hacillyas mahalleleri ile Meşhetlik mahallesinin bir kısmı, Tekye mahallesinin doğu yarısı, Ketenciler, Tırıklı ve Karaali 
mahallelerinin güney kesiminden meydana gelen bir yerleşime sahipti (Akdemir \& İncili, 2014, s. 227). Verimli arazileri sayesinden fethedildikten sonra kadin sultanlara hass olarak tahsis edilmiştir (Çelikdemir, 2020, s. 491).

Halep'e yakın olması zamanla Kilis'i önemli bir ticaret ve konaklama merkezi hâline getirmiştir (Akdemir \& İncili, 2013, s. 80). XIX. yüzyıla kadar şehrin yapısal özellikleri gelişerek yüzyılın sonlarında otuzu aşkın mahallesiyle yuvarlak şehir formunu korumuştur. Ticaret merkezi olarak varlığını koruduğu bilinen ve günümüzde Sabah Pazarı adı verilen yerde bulunan Bedesten 1930 yıllarında yıkılmıştır (Akdemir \& İncili, 2013, s. 84). 1930'larda Bedesten içinde ve dışında Kilis vakıflarına ait birçok dükkânın faaliyette olduğu anlaşılmaktadır (VGM_D_02172_00003, s. $112-123)^{3}$

Kilis, idari bakımdan XIX. yüzyıla kadar Ekrâddan Okcu İzzeddinli, Amiki ve Şeyhler aşiretleri gibi çeşitli mütegallibe ve derebeyleri tarafından yönetilmiştir. 1831'de Misır Valisi Mehmet Ali Paşa'nın oğlu şehri işgal etmiştir (Darkot, 1977, s. 806; Ercivan, 2010, s. 32; Çelikdemir, 2020, s. 491). Kilis 1869 yllında, Azez'in de bağlanması ile daha da büyümüştür. 1914'te Antep'e 1915'de Antep'ten ayrllarak, tekrar Halep'e bağlanmış ise de I. Dünya Savaş1 sırasında Halep'in işgal edilmesi üzerine bağımsız bir sancak olmuştur (Ercivan, 2010, s. 33). 6 Aralık 1918'de İngiliz işgaline uğramıştır (Gülcü, 2012, s. 300). 29 Ekim 1919'da İngilizler işgali Fransızlara bırakmış, Ankara Antlaşması'na kadar Azez'in bir saat güneyine kadar olan kısım Kilis'in siyasi sınırı olarak kalmıştır (Ercivan, 2010, s. 34). Bu anlaşmayla günümüz sınırları belirlenmiştir.

\section{Nüfus ve Toplum}

Fetihten önce Azez'e bağlı bir köy olan Kilis Kanuni Sultan Süleyman'ın 1514 Mercidabık Seferi'nden sonra Canbolad ailesini buraya yerleştirmiş ve bu aileye yurtluk ocaklık ${ }^{4}$ olarak vermiştir (Akdemir \& İncili 2014, s. 227). Ö. Ergenç'in ifadesiyle şehrin önemli işlevlere sahip birimleri olan mahalleler bu dönemde oluşmuş ve toplumsal ilişkilerin düzenlenişinde ve biçimlenişinde büyük bir gelişme olmuştur (Ergenç, 1984, s. 69). İ.Hakkı Konyal1 1519 yllinda Kilis'te 314 nüfus 260 ev bulunduğu ifade etmiştir. (Konyalı, 1968, s. 158) Başka bir araştırma sonuçlarına göre Kilis’in 1519 yılında 6, 1867 yilında 32 ve 1908 yılında 33 mahalleye sahiptir. Bu mahalleler de yazları Kahramanmaraş ve Adıyaman taraflarında kışları Kilis'te konaklayan konargöçer oymak ve Türkmen aşiretlerin iskân edilmesiyle meydana gelmiştir (Akis \& Tektuna 2017, s. 95). 1830-1840 y1lları arasında, şehrin nüfusunun 20 bin olduğu belirtilmektedir (Demir, 2018, s. 107). Ancak bu sayının sadece kaza merkezine ait olup olmadığı kazaya bağlı yerleri de kapsayıp kapsamadığı bilinmemektedir. Halep Salnamesi kayıtlarına göre 1890-1891 y1l kaza nüfusu 72 bin, hane sayısı 4 bin 100'dür. Burada da nüfus sayısının sadece kaza merkezine ait olmadığ anlaşılmaktadır. Zira Ö. L. Barkan'nın önerdiği demografik araştırmalarda genel nüfusun hesaplanmasında hane sayısının 5 rakamıyla çarpılması daha gerçekçi sonuçlara götürecektir. ${ }^{5}$ Bu noktada Kilis kaza nüfusunun 1890 y1lında 20 bin, 1891'de merkez nüfusu 12 bin, hane sayısının da 4 bin 335 olduğu daha gerçekçi görünmektedir (Pamuk, 2020, s.74, 75).

Kilis'te yaşayan gayrimüslim nüfus varlı̆̆ını hep korumuş ancak Müslüman nüfustan hep az olmuştur. Cemaatler arasında farkliliklar söz konusudur. McCarhty Anadolu'da gayrimüslimlerin Anadolu Rumları kuzey ve batı yanda, deniz kıyısı vilayetlerinde yoğunluk oluşturduklarını ifade etmektedir. Yahudiler genelde batı Anadolu kentlerinde yoğunluktaydılar. Ermeniler doğu Anadolu, iç ve batı Anadolu'ya da dağılmışlardır. Doğuda, daha küçük Hristiyan

\footnotetext{
${ }^{3}$ Bu vakıf mülkleri ayrı bir çalışma konusu olarak değerlendirilecektir.

${ }^{4}$ Ocaklık sancaklar hükümet, yurtluk-ocaklık gibi isimlerle fetihten sora hizmeti görülen mahallî bey veya emirlere bırakılan yerlerdir (Kılıç, 2007, s. 317).

5 Ö. Lütfi Barkan 5 genel nüfusu bulmak için bazı yaklaştırıcı hesaplamalar için 5 sayısını önermiştir (Barkan, 195153 , s. 11,12)
} 
toplulukları özellikle (Katolik ve Ortodoks) Süryaniler, Keldani'ler, Nesturi'ler yaşamaktaydılar (McCarthy, 1998, s. 1). Aşağıda görüleceği üzere Kilis'te diğer cemaatlere göre Rum nüfus daha azdır. Kilis’te yaşayan Yahudiler ise Ermeni nüfustan sonra ikinci sırada gelmektedir (Şekil 2).

Cumhuriyetin ilk yıllarında Kilis hakkında bilgi veren Kilisli Kadri kazada azınlık ${ }^{6}$ unsur olarak daha önce Ermeni, Katolik, Yahudi ve Arapça konuşan pek az miktardaki Rum Ortodoks olduğunu yazmaktadır. Ermenilerle Katolikler İstiklal Savaşı sırasında göçüp kaybolmuş, Rumlar da mübadeleye tabi olarak ayrılmış olduklarından Arapça konuşan az miktarda Yahudi kaldığını ifade etmektedir (Kilisli Kadri, 1932, s. 135). Bu tespitler arşiv kayıtları ile de örtüşmektedir. 1265/1849 senesine ait cizye defterine göre Kilis'te Ermeni Rum Yahudi ve Marunîlerin yaşadığını görmekteyiz (BOA_ML_VRD_CMH_d_01493, s.2-15; Şekil 2). Marunîler Katolik mezhebinden olduğu için Kilisli Kadri Marunîleri sadece Katolik olarak anmış olabilir.

Cizye defterleri, cizye mükellefi gayrimüslimlerin kaydedilmesi ile oluştuğundan bu defterler üzerinden kesin bir nüfus hesaplaması yapılamamaktadır. Bu nedenle 1846 ve 1849 yıllarına ait Kilis gayrimüslim nüfusu için net bir rakam telaffuz edemiyoruz.

1869 yllında 7176 hanenin 326's1 gayrimüslim olduğu bilgisine dayanarak hane katsayıs1 5’le çarparsak Kilis'te 1630 gayrimüslim yaşadığını söylemek mümkündür (Günver, 2003, s. 87).

1893 yılına ait nüfus verilerine dayanan Şekil 1'de Kilis'te 4067 gayrimüslim yaşadığ1 görülmektedir (Günver, 2003, s. 89). Bunu hane katsayısı olan 5'e böldüğümüzde 813 gayrimüslim hane olduğu tahmin edilebilir. Bu durumda 1869 ile 1893 yılları arasinda hane sayısının 2,5 kat arttığını söyleyebiliriz. Zira 1846-1849 yıllarında 500-600 vergi mükellefi erkek nüfus söz konusudur. Bu nüfusa dengeli büyüyen kadın nüfusu dahil ettiğimizde en az 1200'e ulaşan bir gayrimüslim nüfus tahmin edilebilir. 1869'da 1630 tahmini sayısına ulaştığımıza göre anılan tarihler arasında Kilis'e gayrimüslim göç dalgasının yaşanmış olabileceğini göstermektedir. Şekil 1'te görülen dışardan gelen yabancı nüfusu çıkardığımızda Kilis'in 68 bin 873 gibi bir nüfusa sahip olduğu görülür. Bunların \% 94'ü Müslüman \%3,69’u Ermeni geriye kalan \%2'ye yakın nüfus da Ermeni Katolik, Rum, Protestan ve Yahudiler oluşturmaktadır. 1881-1882 y1lında Nüfus sayımında Diyarbakır merkez kazasının toplam nüfusunun \% 68’i Müslümandı (Karaboğa, 2020, s. 65). Halep'in 1890'lı y1llarda nüfusunun \%69,78’i Müslüman, \%21,41'i Hristiyan, \%8,81’i Yahudi idi (Demir, 2018, s. 107). Antep şehrinin XVIII. yüzyll nüfusunun yaklaşık \%10’unu gayrimüslimler oluşturuyordu (Demir, 2018, s. 107).

Şekil 1. 1310/1893 Tarihinde Kilis’te Yaşayan Gayrimüslimler

\begin{tabular}{|l|l|l|l|}
\hline & Kadın & Erkek & Toplam \\
\hline İslam & 32.356 & 32.450 & 64.806 \\
\hline Ermeni Katolik & 179 & 168 & 347 \\
\hline Rum & 121 & 180 & 301 \\
\hline Ermeni & 1.221 & 1.323 & 2.544 \\
\hline Protestan & 156 & 177 & 333 \\
\hline Yahudi & 261 & 281 & 542 \\
\hline Yabanc1 & 1.670 & 1.887 & 3.557 \\
\hline Toplam & 35.964 & 36.466 & 72.430 \\
\hline
\end{tabular}

Kaynak: (Günver, 2003, s. 89)

\footnotetext{
6 Osmanlı Devleti'nde gayrimüslimler için zimmî kavramı kullanılmıştır. Türkiye'de azınlık kavramı ise Lozan Konferansı sırasında uzun tartışmalara neden olmuş ve sadece Rum, Ermeni ve Yahudilerin azınlık statüsünde oldukları kabul edilmiştir (Güllü, 2018, s. 269).
} 
Diğer taraftan cizye defterleri uzak veya yakın kazalardan gelen gayrimüslimler hakkında da bilgi vermektedir. Bu bilgiler Kilis'in çevre kazalarla ticari ve sosyal ilişkilerini göstermesi bakımından önemlidir. Bunlar; Halep, Ayntab, Gavurdağ, Sasın ${ }^{7}$ Maraş, Arapgir, Zeytûn, Diyarbekir, Muş, Urfa, Rakka, Gürün, Eğin, Dağlı gibi kaza ve sancak merkezleridir. 652, 933 ve 1493 numaralı cizye defterlerine göre oluşturulan Şekil 2'ye bakıldığında şehir dışından gelen kişi sayısının 111-128 arasında değiştiği görülmektedir. $\mathrm{Bu}$ da şehirde sürekli bir yabancı nüfus hareketliliği olduğunu göstermektedir.

Şekil 2 görüldüğü üzere 1846 yllında 622 kişiden vergi alınmış bunların Kilis’te ikamet edenlerin sayısı 511 dişardan gelenlerin sayısı ise 111 kişidir.

Şekil 2. Cizye Defterlerine Göre Vergi Mükellefleri

\begin{tabular}{|l|l|l|l|}
\hline Tarih & Toplam & Kilisli & Yabanc1 \\
\hline 1846 & 622 & 511 & 111 \\
\hline 1848 & 665 & 537 & 128 \\
\hline 1849 & 722 & 609 & 113 \\
\hline
\end{tabular}

Kaynak: BOA_ML_VRD_CMH_d_652, s. 2-13; 933, s. 2,17; 1493, s. 2-15.

1848 yllı cizye defterine göre dişardan gelenlerin hangi sancak ve kaza merkezlerinden geldiklerini tahlil ettiğimizde Kilis’in çevresiyle ilgili daha açık bir manzara görmek mümkündür. Defterde şahısların isim ve tasvirinin arkasından satır sonunda mütemekkin olduğu kaza merkezi yazılmışır. Dışardan gelip artık Kilis'te ikamet etmeye başlayanlar için "Sasın mütemekkin-i Kilis" şeklinde kaydedilmiştir. Aynı şekilde yine Muş'ta ikamet ettiği anlaşılan 10 kişi de "Sasın mütemekkin-i Muş" şeklinde kaydedilmiştir. Buna göre Kilis’te ikamet edenler 537, dişardan gelenler 128 kişi şeklinde değerlendirme yapılacaktır. Dişardan gelenleri incelediğimizde en fazla gelenlerin $\operatorname{Sasin}^{8}$ gibi uzak bir yerden olması dikkat çekmektedir. Dışardan gelenlerin neredeyse \%36'sını bu kazadan gelenler olușturmaktadır. Sasın'dan olup Muş ve Kilis'te mütemekkin olanları da dâhil ettiğimizde dişardan gelenlerin \%43,4'ü Kilis'le bir bağ kurmuştur. Sasın'lı gayrimüslimlerin Kilis'le hangi noktada yani dini veya ticari anlamda bir bağ kurduklarının izahını şimdilik yapamıyoruz. Ancak bu hususun araştırmaya değecek bir nokta olduğunu da vurgulamak gerekir. İkinci olarak dışardan gelenlerin çoğunluk oluşturduğu yer ise Gavurdağg'dır. Buradan gelenler dışardan gelenlerin \%13,2'sini oluşturmaktadır. Halep'den gelenlerin oranı ise \%12,4'dir. Gavurdağ ve Halep'ten Kilis'e gelenlerin sayısının neredeyse aynı olması ticari ve sosyal hareketliliğin bu yönde canlı ve aynı oranda olduğunu göstermektedir. Dördüncü sırada Muş’ta ikamet eden ve kayıtlarda Muş olarak belirtilenler gelmekte ve oranı \%10,1'dir. Bunların çoğu \%8'e yakını "Sasın mütemekkin-i Muş" şeklinde kaydedilenlerdir. Ardından Arabgir'den gelenler \%5,4, aynı şekilde Zeytûn kazasından gelenler \%5,4 oranına sahiptir. Ayntab ve Dağlı'dan ${ }^{10}$ gelenler ise \%4'erlik bir orana sahiptir. Ayrıca Urfa'dan gelenler \%3,1, Gürün'den gelenler \%2,3, Diyarbekir'den gelenler \%1,6 oranlarda temsil edilmektedir. Rakka, Eğin ve Maraş'tan gelenler ise $\% 1$ 'er oranlarda temsil edilmektedir. Bu durumda herhangi bir vesileyle dişardan gelenlerin yoğunluğuna göre Kilis'e Sasin, Gavurdağ, Halep, Muş, Arapgir, Zeytûn, Ayntab, Dağl1, Urfa, Gürün, Diyarbekir, Eğin, Rakka ve Maraş’tan gelmiştir.

\footnotetext{
${ }^{7}$ Sasın 1578'de sancak olmuş ve Çıldır Eyaleti'ne bağlı bir yer (Sezen, 2006, s. 435).

${ }^{8}$ Defterde bu kelime Sasın (صاصين) şeklinde yazıllmıştır.

${ }^{9}$ Gavurdağ şimdi Hatay il sınırları içinde yer alan şimdiki Nur Dağlarının bulunduğu bölge adı.

10 1865'te Nahiye'dir. Halep Eyaleti sınırları içinde Maraş Pazarcık’a tabi bir yer (Sezen, 2006, s.134).
} 
Taşkın, O. (2021). Ekonomik ve tipolojik bir tahlil: Kilis'te gayrimüslimler (1846-1849),

Mavi Atlas, 9(2), 167-181

Şekil 3, 1849 yılı cizye defterine göre dişardan gelen gayrimüslim nüfusu da gösterecek şekilde düzenlenmiştir. Burada şehir dışından gelenlerin en çoğu 87 kişiyle Ermeni, 17'si Yahudi, 7'si Marunî ve 2'si de Rum cemaatine mensuptur. Ermenilerin şehirdeki gayrimüslim genel nüfus içerisindeki oranlarına benzer bir şekilde dışardan gelenlerinin de fazla olduğu görülmektedir. Kilis'te yaşayan gayrimüslimlerin \%9,03'ü Marunî, \% 71,43’ü Ermeni cemaatine mensuptur. Yahudiler \% 11,17, Rumlar ise \%8,37 gibi bir orana sahiptir. Buna göre Kilis'te yaşayan gayrimüslimlerin \%72'ye yakınını Ermeniler oluşurken diğer cemaatler ise \%10'a yakın oranlarda temsil edilmektedir.

Şekil 3. 1265 (1849) Yılında Kilis’te Cizye Mükellefi Cemaatler

\begin{tabular}{|l|l|l|l|}
\hline & Toplam & Kilisli & Dişardan gelen \\
\hline Marunî & 62 & 55 & 7 \\
\hline Ermeni & 522 & 435 & 87 \\
\hline Rum & 53 & 51 & 2 \\
\hline Yahudi & 85 & 68 & 17 \\
\hline Toplam & 722 & 609 & 113 \\
\hline
\end{tabular}

Kaynak: BOA_ML_VRD_CMH_d_01493, s. 2-16.

1846 yılı cizye defterine göre hazırlanan veriler Şekil 4.'te görülmektedir. Bunların içerisinde gelir düzeyi yüksek olan 7 kişi Kilis'te ikamet etmektedir. Evsât ve ednâ sinıfindan vergi verenlerin daha fazla olduğu açıkça görülmektedir. Dışardan gelenlerin çoğunluğunun da ednâ sınıfından vergi verdiğine bakılırsa ticaret için gelenlerin de çok da iyi bir ekonomik sınıfa mensup olmadıklarını söyleyebiliriz. Tabi başka bir amaç için gelmiş olanlar da olabilirler. Bu tür hareketlilik diğer şehirlerde de söz konusu olmuştur. 1847 yllında Amasya'da cizyesini ödeyen ve hanlarda misafir olarak kalan yabanc1 70 kişi Kayseri, Tokat, Diyarbakır, İstanbul, Sivas, Van, Halep gibi uzak şehirlerden geldikleri ifade edilmiştir (Eken, 2016, s. 111).

Şekil 4. 1262 (1846) Yilında Kilis'te Cizye Mükellefi Yerli ve Yabancılar

\begin{tabular}{|l|l|l|l|l|}
\hline & Alâ & Evsât & Ednâ & Toplam \\
\hline Yerli & 7 & & & 420 \\
\hline Yerli & & 225 & & 6.750 \\
\hline Yerli & & & 279 & 4.185 \\
\hline Yabanc1 & & 35 & & 1.050 \\
\hline Yabanc1 & & & 76 & 1.140 \\
\hline Toplam & 7 & 260 & 355 & 13.545 \\
\hline
\end{tabular}

Kaynak:(BOA_ML_VRD_CMH_d

00652), s.13

1848 tarihli cizye defterine göre hazırlanan Şekil 5'te görüldüğü üzere Kilis'te yaşayan ve vergisini veren gayrimüslimlerin \%76's1 21-50 yaş aralığındadır. 21-30 yaş aralığında bulunan gayrimüslimler \%34,16'dır. Kilisli gayrimüslimlerin genel yaş ortalamasına baktı̆̆ımızda ise 32,8 civarında oldukça genç bir yaş ortalamasına sahip oldukları anlaşılmaktadır. 80 ve 90 yaşında iki tane yaşlının da düşük gelir seviyesinden vergi verdiği görülmektedir. En küçük vergi veren 14 yaşında bir kişi de Arapkir'den gelmiştir. Ayrıca cizye ödeyenlerin 15 ve 72 yaş aralığında oldukları görülmektedir. 
Taşkın, O. (2021). Ekonomik ve tipolojik bir tahlil: Kilis'te gayrimüslimler (1846-1849),

Mavi Atlas, 9(2), 167-181

Şekil 5. 1264/1848 Yılı Cizye Vergi Mükellefi Gayrimüslimlerin Yaşları

\begin{tabular}{|c|c|c|c|c|c|c|}
\hline Yaş aralığ1 & kişi sayısı & edna (15) & evsat (30) & âlâ $(60)$ & Kilis'li & Yabanc1 \\
\hline $14-20$ & 93 & 85 & 8 & & 77 & 16 \\
\hline $21-30$ & 252 & 193 & 58 & 1 & 182 & 70 \\
\hline $31-40$ & 180 & 101 & 79 & & 152 & 28 \\
\hline $41-50$ & 85 & 33 & 49 & 3 & 72 & 13 \\
\hline $51-60$ & 42 & 24 & 17 & 1 & 39 & 3 \\
\hline $61-72$ & 11 & 6 & 3 & 2 & 9 & 2 \\
\hline 80-- & 1 & & 1 & & 1 & 0 \\
\hline 90-- & 1 & & 1 & & 1 & 0 \\
\hline Toplam & 665 & 442 & 216 & 7 & 533 & 132 \\
\hline
\end{tabular}

Kaynak: BOA_ML_VRD_CMH_d_00933,s.2-17.

Yine Şekil 5’te yaş aralıklarına baktığımızda şu sonuçlara ulaşmak mümkündür. 15 yaş altı nüfus hariç olmak üzere gayrimüslimlerin \%14,69'u 15-20 yaş aralığındadır. \%34,16's 21-30 yaş, \%28,44'ü 31-40 yaş, \%13,36's1 41-50 yaş, \%7,25’i 51-60 yaş, \%1,72'si 61-72 yaş aralığındadır. 1833 Sivas ili merkez kazası Gayrimüslim nüfus defterleri kayıtlarına göre kayıtlı erkek nüfusun \%30'u 0-9 yaş aralığında, \%33’ü 10-29 yaş aralığında, \%23’ü 30-49 yaş aralığında, \%14’ü ise 50 yaşın üstündedir (Zabun, 2018, s. 61). Bu verilere baktığımızda Sivas'ta yaşayanlarla Kilis merkezde yaşayan gayrimüslimlerin 15-30 yaş aralığındaki nüfusun neredeyse aynı olduğu görülmektedir. Ancak 30-50 yaş aralığındaki kişilerin oranı Kilis'te \%41,79'u bulmaktadır. 50 yaş üzerindeki kişi sayısının Sivas'ta daha fazla olduğu görülmektedir. Burada aksakallı olanların oranının \%36 olması da bunu teyit etmektedir (Zabun, 2018, s. 63). Kilis'te aksakallı veya 50 yaş üstü kişilerin oranı sadece $\% 2$ 'dir. Bu durumda Kilis'teki nüfusun daha genç bir ortalamaya sahip olduğu ortaya ç1kmaktadır.

\section{Gayrimüslimlerin Ekonomik Durumları}

Gayrimüslimlerin cizye vergisinin toplanmasında ekonomik durumlarına göre üç sinıfa ayrıldığını ifade etmiştik. Bununla ilgili kısa bir tarihi malumat verecek olursak III. Murad zamanında cizye miktarları alâ, evsât ve ednâ şeklinde sırasıyla 45, 30, 15 akçe olarak belirlenmiş Köprülü Fazıl Mustafa Paşa’nın sadrazamlığı döneminde cizye miktarları yeniden ayarlanmıştı. 1856 yilına kadar da alâ 60, evsât 30 ve ednâ 15 kuruş olarak kalmıştır (Karaboğa, 2020, s. 62). Kullandığımız cizye defterlerinde de bu miktardan cizye toplanmıştır. Osmanlı Devleti'nde genel uygulamaya göre kaza dişından gelenler veya gezgin tüccarlar vergisini ödediği şehirlerdeki defterlere kaydedilirdi (Çalışkan, 2020, s. 980). Bu durum 14 Mayıs 1855 tarihinde cizye vergisinin kaldırıldığı kamuoyuna duyurulmasına kadar devam etmiştir. Askerlik görevinin gayrimüslimler için de kutsal bir görev olduğu belirtilerek onların da istisnasız askere gidecekleri ilan edilmiştir (Gülsoy, 2002, s. 94). Cizye kaldırıldıktan sonra askere gitmek istemeyenlerden "bedel-i askeri" adı altında vergi alınmaya devam etmiştir. Kilis’te de aynı şekilde gayrimüslim erkeklerden askerlik bedeli toplanmış ve diğer vergilerle birlikte kazanın idari giderlerine harcanmıştır (Pamuk, 2020, s. 233).

Kilis'in ekonomik faaliyetleri hususu daha geniş bir çalışmanın konusu olabilir ancak genel anlamda Kilis'te ekonomik faaliyetlerden en önemlisini tarımsal faaliyetler oluşturmuştur. (Ercivan, 2010, s. 10). Süveyş Kanalı'nın açılmasıyla Kilis ekonomisinin gerilediği, Meşrutiyet 
döneminde biraz canlandiğı ifade edilmektedir (Günver, 2003, s. 104). Şimdilik bu konuda henüz somut verilerin ortaya konulduğunu söyleyemeyiz.

Ekonomik faaliyetin en önemli ayağ1 elbette şehirlerarası ticaretti. Bu konuda gayrimüslimlerin önemli bir yeri olduğu bilinmektedir. Bilhassa Ermeniler şehirlerarası ticarette önemli bir yer işgal etmişlerdir. Özellikle Halep bağlantılı ticarete büyük ilgi gösteren gayrimüslimler Anadolu'nun iç bölgelerinden gelerek ticaretle meşgul olmuşlardır. Örneğin Elazığ-Palu'nun Diyarbakır ve Halep'le yapılan ticaretin büyük bir çoğunluğunu Ermeniler ellerinde tutmuşlardır (Dalyan, 2011, s. 137). Kilis’e dişardan gelen gayrimüslimlerin çoğunluğu Sasın'dan sonra en fazla Halep ve Gavurdağ'dan gelenler oluşturmuştur. Bu konuda bölgesel ticaret ve özelde Kilis halkı için genelleme yapmaktan kaçınsak Sasın, Halep ve Gavurdağ arasında iktisadi ilişkilerin yoğunlaştı̆̆1 ticari bir yol güzergahı olduğu ve bu noktada yoğunlaştı̆̆1 noktasında önemli bilgiler sunmaktadır. Buna ek olarak kuzeyden başlayarak bir bölgesel ticari ilişkiler ağı kurulmuş olduğu anlaşılmaktadır. Bu bölgeyi kabaca tarif ettiğimizde Gürün'den başlayıp doğuya doğru Eğin'e, Sasın’a ulaşmaktadır. Tekrar güneye dönerek Muş, Diyarbakır, Urfa ve daha güneyde Rakka'ya ardından dönüp Halep'i içine alan çemberin bir tarafinı oluşturmaktadır. Maraş ve Gavurdağ ve Kilis'le tamamlanan bir diğer tarafı olmak üzere büyük bir çember Kilis'in bölgesel ticari ilişkilerinin sınırlarına işaret etmektedir (BOA_ML_VRD_CMH_d_00933, s.2-17).

$\mathrm{Bu}$ çevrede ticari faaliyet içerisinde bulunan gayrimüslimlerin ekonomik durumları özelde Kilisli gayrimüslimler için ancak genelde de bu bölgenin insanlarına dair bilgiler sunmaktadır. Bir başka deyişle bu bölgede ticari ilişkiler kuran gayrimüslimlerin kazançları ve gelir düzeyleri ne durumda olduğunu Kilis’te yaşayanlardan öğrenmek mümkündür. Bu hususta ilk tespitler şu şekilde olacaktır: Birincisi Kilis'te yüksek gelirli gayrimüslim var ancak genel olarak ekonomik durumlarının çok iyi olduğu söylenemez. Şekil 4'e bakılırsa Kilis'te ikamet eden alâ sınıfindan vergi veren yüksek gelirli sadece 7 kişi vardır. Orta düzeyde gelire sahip kişi sayısı ise 260 olup bu sayı cizye verenlerin \%41,80’ini oluşturmaktadır. Düşük gelir seviyesine sahip 355 kişi ise ednâ sınıfında vergi vermişlerdir. Bu da \%57,07’sinin çok düşük ekonomik gelire sahip olduğu anlaşılmaktadır. Toparladığımızda Kilis’te yaşayan gayrimüslimlerin orta ve düşük gelir seviyesine sahip olup bunların sadece \%1'nin ekonomik durumu iyidir. Öte yandan alâ sınıfından vergi vermiş olması çok zengin olduğunu da göstermese gerekir.

Şekil 6'da 1848 yılı vergi kayıtları incelenmektedir. 1846 yılında olduğu bu yılda da 7 tane alâ sınıfindan vergi veren gayrimüslim vardır. $\mathrm{Bu}$ muhtemelen aynı kişilerdir. 216 kişi evsât sınıfından vergi vermiş 442 kişi de ednâ sınıfından vergi vermiş oldukları görülmektedir. Burada evsât sınıfından ödeme yapanlar cizye ödeyenlerin \%32,38’ini oluşturmaktadır. Geriye kalanlar da ednâ sınıfindan cizye vergisi ödemişler ve bu kişiler vergi mükellefi gayrimüslimlerin \% $\% 66,57$ 'sini meydana getirmektedir. Geriye kalan \%1'lik dilim de alâ sınıfından olanları temsil etmektedir. Görüldüğüüzere gayrimüslimlerin neredeyse 2/3’ü düşük gelire sahip kişilerden oluşmaktadır.

Şekil 6. 1264/1848 Senesi Cizye Vergisi Mükellefleri

\begin{tabular}{|l|c|c|c|c|}
\hline Cizye sınıfi & Ednâ (15) & Evsât (30) & Alâ (60) & Toplam \\
\hline Kişi sayısı & 442 & 216 & 7 & 663 \\
\hline Miktar & 6.630 & 6.480 & 420 & 13.530 \\
\hline
\end{tabular}

Kaynak: BOA_ML_VRD_CMH_d_00933,s. 17 
1849 yılına ait 1493 numaralı cizye defterine göre hazırlanan Şekil 7'de Kilis'te toplam 722 cizye veren kişiden toplam 13 bin 695 kuruş alındığı görülmektedir. Burada daha önceki ylllarda alâ sınıfindan 5 kişinin olmadığı sadece 2'sinin olduğu görülmektedir. Bunun kabaca üç sebebi olabilir. Bunlardan birincisi bu kişiler şehir dışına çıkmış olabilirler. İkincisi ekonomik anlamda gelir seviyeleri düşmüş bir alt sınıftan vergisini ödemiş olabilirler. Sonuncusu da ölmüş olabilirler. Bu konuda kesin bir yargiya varmak söz konusu değildir. Vergisini ödeyenlerin \%25,6'sından yani 185 kişiden 5 bin 550 kuruş tahsil edilmiştir. Geriye kalan cizye mükelleflerinin \%74'ünden yani 535 kişiden ise toplam 8025 kuruş tahsil edilmiştir. Bu duruma başka bir açıdan bakmak istediğimizde diğer şehirlerde yaşayanlara bakmak yararlı olacaktır. XVIII. yüzyıl başlarında Maraş, Malatya ve Antep'te bulunan cizye mükellefi gayrimüslimlere ait veriler işe yarar gözükmektedir. $\mathrm{Bu}$ üç şehirde yaşayan gayrimüslimlerin üç sınıfta; âlâ, evsât ve ednâ sınıflarına göre oranlarının alâ $\% 10$, evsât \%80 ednâ \%10 şeklinde gerçekleștiği anlaşılmaktadır (Çalışkan, 2020, s. 975). Yani Kilis'te yaşayan gayrimüslimlerin daha çok evsât ve ednâ sınıfinda yoğunlaştığı, adı geçen üç şehirde alâ sınıfında ve ednâ sınıfında daha orantılı bir ekonomik yapı göze çarpmaktadır.

\section{Şekil 7. 1265/1849 Senesi Cizye Vergisi Mükellefleri}

\begin{tabular}{|l|r|r|r|r|}
\hline Cizye sınıfi & \multicolumn{1}{|c|}{ Ednâ (15) } & Evsât (30) & Alâ (60) & Toplam (kuruş) \\
\hline Kişi sayıs1 & 535 & 185 & 2 & 722 \\
\hline Miktar & 8.025 & 5.550 & 120 & 13.695 \\
\hline
\end{tabular}

Kaynak: BOA_ML_VRD_CMH_d_01493, s. 2-17

1729 yllında Maraş’ta bulunan gayrimüslimlerin \%13'ü alâ, \%79 evsât ve \%8’i ednâ sınıfindan cizye vergisini ödemişlerdir. Bu durum Maraş’ta gayrimüslimlerde orta gelir düzeyinde yoğunlaşmış bir sosyal sınıf oluştuğunu göstermektedir. 1818 yllında aynı şehirde 5084 gayrimüslimden 352 kişi yani \%7'si alâ, 3 bin 741 kişi \%74'ü evsât, 991'i \%19'u ednâ sinıfindan vergi ödemişlerdir. Yaklaşık 90 yıllık bir süreçte yüksek ve orta gelir düzeyinde bir azalma olurken düşük gelir seviyesinde bir yükselme söz konusu olmuştur. Yani gelir seviyesinde genel anlamda bir düşüş olmuş gelir düzeyi düşük olanların oranı \%8'den \% 19'a çıkarak iki kattan fazla artmıştır. 1847 yllında ise Maraş’ta yaşayan toplam 2 bin 877 gayrimüslimden 244 kişi yani \%8'i alâ sınıfindan, 2 bin 65 kişi \% 72'si evsât, 568 kişi \%20'si de ednâ sınıfindan vergi vermişlerdir. Bu durumda Maraşlı gayrimüslimlerin 1818 yılındaki durumlarını korudukları ortaya çıkmaktadır (Çalıskan, 2020, s. 979). Bir diğer yandan 1833 Sivas merkez kazası gayrimüslim nüfus defterleri kayıtlarına göre 95 kişi yani nüfusun \%3’ü alâ, 2241 kişi \%74'ü evsât, 204 kişi \%7'si ednâ sınıfindan kayda geçirilmiştir. Bunlarda başka \%16’s1 da cizye vergisi ödememekte veya başka yerde ödemekte oldukları belirtilmiştir (Zabun, 2018, s. 55). Bu noktadan bakıldığında gerek Maraş gerek Sivas şehirlerinde gayrimüslimlerin orta gelir düzeyinde daha fazla yoğunlaştıkları görülmektedir. Buna karşın Kilis kazasında ednâ sınıfında cizye ödeyenlerin daha kalabalık bir gurubu oluşturmuşlardır. Kilis'te düşük gelirli kişi oranı 1846'da orta gelirlilere yakınken daha sonra artmıştır (Şekil 4-7). 1849 yılında \%74'ü ednâ sınıfından vergi verirken diğer her iki şehirde evsât sınıfından vergi verenler bu orandadır. Netice itibariyle Kilisli gayrimüslimlerin Sivas ve Maraşlılara göre daha düşük bir ekonomik seviyeye sahip oldukları anlaşılmaktadır.

Diğer bir nokta da gayrimüslim cemaatlerin kendi aralarında vergi sınıflarına göre karşılaştırılmasıdır. Şekil 8 buna göre hazırlanmıştır. Buna göre Ermeni, Maruni, Yahudi ve Rum cemaatlerinin çoğunluğu alt gelir sınıfina mensup oldukları açıkça görülmektedir. Ermenilerin \%74,1'i, Marunîlerin \%64,5’i, Yahudilerin \%81,2'si ve Rumların \%73,6'sı ednâ sınıfindan vergilerini ödemişlerdir. Burada Yahudilerin bilinenin aksine ekonomik anlamda diğer cemaatlere 
göre daha düşük ekonomik seviyeye sahip olmalarına dikkat çekmektedir. Ekonomik anlamdan Marunîler daha iyi bir ekonomik seviyeye sahiptirler. Hem orta sınıf seviyesinde vergi verenlerin oranı diğerlerine göre yüksek hem de alâ sınıfından iki vergi mükellefi bu cemaate mensuptur. Bunların birisi Kilis diğeri Haleplidir. Marunîlerin evsât sınıfından vergi veren kişilerinin oranı \%32,3 iken en kalabalık gayrimüslim topluluğunu oluşturan Ermenilerin bu sınıfta vergi verenlerin oran1 \%25,9'dur. Bu oranlar Yahudilerde \%18,8, Rumlarda \%26,4'tür. Bu durumda Ermenilerin ve Rumların ekonomik anlamda aynı seviyede olduklarını söyleyebiliriz. Yahudiler diğer cemaatlere göre düşük gelirli olup bunların 18,8'i evsât sınıfindan vergi öderken \%81,2'si ednâ sınıfından vergilerini ödemişlerdir.

Şekil 8. 1265/1849 Y1lı Verilerine Göre Gayrimüslimlerin Ekonomik Durumları

\begin{tabular}{|l|c|c|c|c|}
\hline & Ermeni & Marûni & Yahudi & Rum \\
\hline Alâ & & 2 & & 16 \\
\hline Evsât & 135 & 20 & 69 & 39 \\
\hline Ednâ & 387 & 40 & 85 & 53 \\
\hline Toplam 722 & 522 & 62 & & 16 \\
\hline
\end{tabular}

Kaynak: BOA_ML_VRD_CMH_d_01493, s.2-16

\section{Gayrimüslimlerin Tipolojik Değerlendirmesi}

Cizye defterlerinde gayrimüslimler boy ve şekil olarak tarif edecek tanımlamalarla kaydedilmiştir. Orta boylu aksakallı Bedros veledi Abraham, Orta boylu kara sakallı Maksimibaş veledi Ohan gibi tanımlama mevcuttur. Boyları ile ilgili olarak ise kısa, orta, uzun şeklinde tarif edilmişlerdir. Fiziksel görünümlerinin en belirgin tarafı olan saç ve sakal renkleriyle tanımlanmış ve bunlar beyaz, kır, kızıl, kumral, kara, köse, sar1, boz, teze ve ter gibi ifadelerle tasvir edilmişlerdir. Sakallı olmayanların bıyık renkleri belirtilmiş, bıyığ yeni çıkanlar için teze ve biraz kararan gençler için ter biyıklı tabiri kullanılmıştır. Bu çerçevede 933 numaralı cizye defteri esas alınarak Şekil 9 hazırlanmıştır. Aksakallı veya beyaz sakallı olarak kaydedilen 13 kişinin yaş ortalaması 64 olduğuna göre yaşları itibariyle beyazlamış sakallarını tarif etmişlerdir. Kır renkli iki kişi de 60 yaşlarında olduğuna göre beyazlaşmaya başlamış olduğu anlaşılmaktadır. 35 kişi kızıl sakallı olarak tarif edilmiş ve kaydedilmiştir. Kırmızıya yakın kızıl sakallı kişiler genelin \%05,26'sını oluşturmaktadır. Kumral renkli olanlar ise 125 kişi olup genelin \%18,80'ini oluştururken kara sakallılar 219 kişiyle \%33'e yakın bir orana sahiptir. Sarı renkli 74 kişi \%11,13, boz renkli olanlar 47 kişi \%7 gibi bir orana sahiptir. Ter biyıklı 133 genç genelin \%20'sini oluştururken bunların yaş ortalamaları 21'dir. Sakallı olanların yaș ortalaması 43 iken biyıklı olanların yaș ortalaması ise 29'dur. Gayrimüslimlerde sakal bırakma oranına baktığımızda \%26 oranla 175 kişi olduğu görülmektedir. 665 kişinin 490'ı yani \%74'ünün sadece bıyık bıraktı̆̆ı, yaş ilerledikçe sakal bırakmanın adet olduğunu söyleyebiliriz (BOA_ML_VRD_CMH_d_00933, s. 2-17).

Sakal bırakanların yaş aralıklarına baktığımızda 15-20 yaş aralığında 4 kişi sakallı olup sakal bırakanların \%2,29'una denk gelmektedir. 21-30 yaş arası sakal bırakanların sayısı ise 23 kişi olup \%13,14'üne denk gelmektedir. 31-40 yaş aralığında sakal bırakanların sayısı 50 olup \%28,57, 41-50 yaş aralığında sakal bırakanların sayısı ise 54 olup \% 30,86'ya denk gelmektedir. 51-60 yaş aralığında sakallı olanların oranı ise \%20'dir. 61-90 yaş aralığında sakallı olan 9 kişi sakal bırakanların \%5,14'üne denk gelmektedir. Bu bilgilere dayanarak her yaş aralığında sakal bırakıldığı ancak daha çok 30-50 yaş aralığında sakal bırakmanın adet olduğu görülmektedir. Bıyık bırakanların yaş ortalamasına baktığımızda genç yaşlarda bıyıklı oranlarının yükssek olduğu görülür. 15-20 arası 89 kişinin bıyıklı sadece 4 kişinin sakallı olduğu anlaşılmaktadır. Bu yaş aralığında olanlar bıyık bırakanların \%18'ini oluşturmaktadır. Bıyıklı olanların çoğu 21-30 aralığında olup 230 kişi ile bıyıklıların \%47'sini oluşturmaktadır. 31-40 yaş aralığında bıyıklı olan 129 kişi bıyıklıların 
Taşkın, O. (2021). Ekonomik ve tipolojik bir tahlil: Kilis'te gayrimüslimler (1846-1849),

Mavi Atlas, 9(2), 167-181

\%26'sını oluşturmaktadır. 41-50 yaş aralığında sadece 31 kişi bıyıklı olup bıyıklıların \%6'sını oluşturmaktadır. 55-70 yaş aralığında sadece 11 kişi vardır. Genel olarak baktığımızda 665 kişinin \%67'si bıyıklı ve 40 yaşın altındadır. Sakal bırakma adeti yaşın ilerlemesiyle orantılı ancak yaşı ilerlemiş de olsa sakal bırakmayanlar da mevcuttur (BOA_ML_VRD_CMH_d_00933, s.2-17).

Şekil 9. Gayrimüslimlerin Sakal Bıyık Renkleri ve Yaş Ortalamaları

\begin{tabular}{|l|l|l|l|}
\hline & Say1 & Yaş ortalamas1 & Genele oran1 \% \\
\hline Beyaz & 13 & 64 & 1,95 \\
\hline Kur & 2 & 60 & 0,30 \\
\hline Kuz1 & 35 & 49 & 5,26 \\
\hline Kumral & 125 & 36 & 18,80 \\
\hline Kara/siyah & 219 & 34 & 32,93 \\
\hline Köse & 6 & 32 & 0,90 \\
\hline Sar1 & 74 & 32 & 11,13 \\
\hline Boz & 47 & 28 & 7,07 \\
\hline Teze/Taze & 11 & 22 & 1,65 \\
\hline Ter & 133 & 21 & 20,00 \\
\hline Toplam & 665 & & 100,00 \\
\hline
\end{tabular}

Kaynak: BOA_ML_VRD_CMH_d_00933, s. 2-17

Boyları itibariyle baktı̆̆ımızda 495 kişinin yani \%74,4’ünün orta boylu, 107 kişinin \%16,1'nin uzun boylu, 63 kişinin \%9,5’inin de k1sa boylu olduğu görülmektedir (BOA_ML_VRD_CMH_d_00933, s.2-17). 1833 Sivas kazas1 gayrimüslim nüfus defterleri kayıtlarına göre kayıtlı erkek nüfusun \%62'sinin orta boylu, \% 18'inin uzun boylu, \% 10'unun uzunca boylu ve yine yaklassık \% 10'unun kısa boylu olduğu görülmektedir (Zabun 2018, s. 59). Kilisli gayrimüslimlerin boyları itibariyle Sivaslı gayrimüslimlerle aynı oranlara sahip olmaları genel tip olarak iki şehirde yaşayan gayrimüslimlerin farklı olmadıkları aynı standartlarda bir tipolojiye sahip olduklarını göstermektedir.

\section{Sonuç}

$\mathrm{Bu}$ çalışma neticesinde 1846 ve 1849 yılları arasında Kilis'te 1500-1600 civarında gayrimüslim yaşadığ1 tahmin edilmiştir. Ekonomik ilişkilerin çevre şehirlerle oldukça yoğun olduğu görülmüss ve Sasın başta olmak üzere Halep, Gavurdağ, Arapgir, Diyarbakır, Eğin, Gürün, Maraş, Rakka, Muş, Urfa, Zeytûn gibi Doğu ve Güney doğu Anadolu şehirleriyle Suriye bölgesinden Kilis'e gayrimüslimlerin geldikleri ve bu sayının yıllara göre 100-130 civarı bir aralıkta değiştiği anlaşılmıştır. Maraş ve Sivas gibi daha büyük şehirlerde yaşayan gayrimüslimlerin daha yüksek gelir düzeyine sahip oldukları ve orta gelir seviyesinde yoğunlaştıkları görülürken Kilis’te yaşayan gayrimüslimlerin ekonomik anlamda alt gelir sınıfında yoğunluk oluşturdukları tespit edilmiştir. Özellikle Yahudi cemaatinin en düşük ekonomik seviyeye sahip gayrimüslim cemaatini oluşturduğu görülmüştür. Marunîlerin bölgede daha iyi bir ekonomik ilişkiler kurmuş olmalılar ki diğer cemaatlere göre daha iyi bir ekonomik düzeyde oldukları anlaşılmaktadır. Kilis'te en kalabalık gayrimüslim cemaati oluşturan Ermenilerin ekonomik anlamda Rumlarla aralarında pek bir fark olmadığ1 görülmüştür. Yaşam süreleri açsından baktı̆̆ımızda Maraş’ta yaşayan gayrimüslimlerden ileri yaşlardaki kişi sayısının Kilis’tekilere göre daha fazla olduğu görülmüştür. Bu durum insanların ekonomik seviyeleri ile yaşam uzunlukları arasındaki ilisski düşünüldüğünde ekonomik durumlarının yaş ortalamalarını da etkilediğini söylemek mümkündür. Tipolojik olarak 
Taşkın, O. (2021). Ekonomik ve tipolojik bir tahlil: Kilis'te gayrimüslimler (1846-1849),

Mavi Atlas, 9(2), 167-181

gayrimüslimlerin genelde sakal bırakmadıkları \%75'nin bıyık bırakmanın adet olduğu anlaşılmıştır. Sakal bırakma adetinin daha çok ileri yaşlarda özellikle 30-50 yaşlarında olduğu görülmüştür. Sakal bırakmanın çok yaygın olduğu bir sosyal çevrede sakal bırakanların yaş ortalaması 43 olarak gerçekleşmiştir. Sakallı olanlarda kara ve kumral renkli olanların daha fazla ve yaş ortalamasının 34 ve 36 olması Kilis’te yaşayan gayrimüslimlerin genç bir nüfusa sahip olduklarını göstermektedir. Genel yaş ortalamasının 33 olması da bu durumu açıklamaktadır. Azda olsa genç yaşta sakal bırakan olduğu gibi ileri yaşlarda sakal birakmayanlar da bulunduğu görülmüştür. Sakal bırakmanın adet haline gelmediği söylenebilirken bıyık bırakmanın ise yaygın bir tercih olduğu görülmüștür. Kilisli gayrimüslimlerin bir bütün olarak tipolojik özellikleri dikkate alındığında çevre şehirlerdeki gayrimüslimlerle benzer özellikler taşıdıkları görülmektedir.

\section{Kaynakça}

\section{Arşiv Kaynakları}

Vakıflar Genel Müdürlüğü Arşivi Defteri: VGM_D_02172_00003

Başkanlık Osmanlı Arşivi Maliye Nezareti Varidat Muhasebesi cizye Defteri: BOA_ML_VRD_CMH_d_00652, 2-13

BOA_ML_VRD_CMH_d_00933, 2-17.

BOA_ML_VRD_CMH_d_01493,2-15.

Başkanlık Osmanlı Arşivi Halep Salnamesi 1302/1885.

\section{Araştırma Eserler}

Adıyeke, N. (2014). Osmanlı millet sistemine dair tartışmalar ve siyasal bir uzlaşma modeli olarak Osmanlı millet sistemi. Yeni Türkiye, 60, 345-357.

Akdemir, İ. O \& İncili, Ö. F. (2013). Şehir morfolojisi ve iktisadi yapı ilişkileri: XIX. yüzyıl Kilis şehir örneği, Sosyal Bilimler Dergisi, 3(6), 79-101.

Akdemir, İ. O \& İncili, Ö. F. (2014). Coğrafi ortam ve kent fizyolojisi ilişkileri: XIX. yüzyıl Kilis şehri örneği, Marmara Coğrafya Dergisi, 29, 220-247. https://doi.org/10.14781/mcd.26778.

Akis, M \& Tektuna, M. (2017). Hurûfât defterlerinde 17-19 yüzylllar arasında Kilis'te sosyal ve dini hayat, Sosyal Bilimler Dergisi, 7(14), 88-103. https://doi.org/10.31834/kilissbd.354630.

Barkan, Ö.L. (1951-1953). Tarihi demografi araştırmaları ve Osmanlı tarihi. İstanbul Üniversitesi Türkiyat Enstitüsü Türkiyat Mecmuası, 9, 1-25.

Braude, B. (1999). Millet sisteminin ilginç tarihi. İçinde Osmanl Taribi Ansiklopedisi (Cilt 4, ss. 245-255). Yeni Türkiye Yayınları.

Çalışkan, A. (2020). Cizye defterlerine göre Maraş’ta gayrimüslimlerin ekonomik durumlar1. Kahramanmaraşs Sütçü İmam Üniversitesi Sosyal Bilimler Dergisi, 17(2), 967-986 https://doi.org/10.33437/ksusbd.726821.

Çelikdemir, M. (2020). Kilis voyvodası el-Hac Mehmed'in öldürülmesi (M.1714/H. 1126). Firat Üniversitesi Sosyal Bilimler Dergisi, 30(2), 491-504. https://doi.org/10.18069/firatsbed.752231.

Çoruh, H. (2020). Cizye tahrirlerine göre Antakya'da gayrimüslim cemaatler. Vakanüvis Uluslararası Tarih Araşttrmalar Dergisi, 5(1), 74-124. https://doi.org/10.24186/vakanuvis.670216. Kitap.

Dalyan, M. G. (2011). XIX. yüzyılda gelenekten Batı kültürüne geçişte Ermeni yaşamı. Öncü 
Taşkın, O. (2021). Ekonomik ve tipolojik bir tahlil: Kilis'te gayrimüslimler (1846-1849),

Mavi Atlas, 9(2), 167-181 Bakanlığ1.

Darkot, B. (1977). Kilis. İçinde İslam Ansiklopedisi (Cilt 6, ss. 806-808). Milli Eğitim

Demir, E. (2018). Osmanlıda gayrimüslim nüfusu ve yerleşimi: 19. yüzyılda Ayıntab örneği. Nüfusbilim Dergisi, 40, 105-125.

Demirkent, I. (1992). Haçlı seferleri dönemi kalelerinden Râvendân. Belleten, 56(216), 371-390.

Eken, G. (2016): Tanzimat dönemi cizye defterlerine göre Amasya'da gayrimüslimler. Gaz̧iosmanpaşa Üniversitesi Sosyal Bilimler Araștormalar Dergisi, 11(1), 105-132. https://doi.org/10.19129/sbad.45.

Ercan, Y. (1991). Osmanlı İmparatorluğu'nda gayrimüslimlerin ödedikleri vergiler ve bu vergilerin doğurduğu sosyal sonuçlar. Belleten, 55(213), 371-392.

Ercivan, H. (2010). 19. yürynlda sosyo-ekonomik yönüyle Kilis kazası (Tez No. 274058) [Yüksek Lisans, Marmara Üniversitesi]. YÖK Ulusal Tez Merkezi.

Ergenç, Ö. (1984). Osmanlı şehirlerindeki “mahalle”nin işlev ve nitelikleri üzerine. Osmanl Araștirmalar, 4, 69-78.

Gülcü, E. (2012). Milli mücadele döneminde Kilis. Kilis 7 Arahk Üniversitesi İlabiyat Fakültesi Dergisi, 2(3), 1-37.

Güllü. R.E. (2018). Lozan Antlaşması sonrası Türkiye'nin azınlıklara yönelik politikaları. Avrasya Incelemeleri Dergisi, 7(2), 268-298.

Gülsoy, U. (2002). Osmanl gayrimüslimlerinin askerlikten muafiyet vergisi: bedel-i askeri (1855-1909). Tarih Dergisi, 37, 93-118.

Günver, K. (2003). Kilis'te yaşayan gayrimüslimler (Tez No. 137265) [Yüksek Lisans Tezi, Gaziantep Üniversitesi). YÖK Ulusal Tez Merkezi.

İnalc1k, H. (1993). Cizye. İçinde İslam Ansiklopedisi (Cilt 8, s. 45-48). Türkiye Diyanet Vakfi Yayınları.

Karaboğa, D. V. (2020). Diyarbekir gayrimüslimlerinde sosyal ve hukuki yaşam (18381909). Süleyman Demirel Üniversitesi Fen-Edebiyat Fakültesi Sosyal Bilimler Dergisi, 51, 61-73.

Kenanoğlu, M. M. (2013). Zimmî. İçinde İslam Ansiklopedisi (Cilt 44, ss. 438-440). Türkiye Diyanet Vakfi Yayınları.

Kesici, Ö. (2011). Kilis'in şehir coğrafyası özelliklerine genel bir bakış. Doğu Coğrafya Dergisi, 1(1), 246-280.

Kılıç, O. (2007). Ocaklık. İçinde İslam Ansiklopedisi (Cilt 33, ss. 317-317). Türkiye Diyanet Vakfı Yayınları.

Kilisli Kadri (1932). Kilis taribi. Bürhaneddin Matbaas1.

Kocaoğlu, B. (2018). 1844 ve 1846 tarihli Çankırı cizye defterlerine göre Çankırı'da gayrimüslimler. Alinteri Sosyal Bilimler Dergisi, 2(4), 283-295. https://doi.org/10.30913/alinterisosbil.440669.

Konan, B. (2015). Gayrimüslim Osmanlı vatandaşlarının hukuki durumuna ilişkin bir değerlendirme. Ankara Üniversitesi Hukuk Fakültesi Dergisi, 64(1), 171-193. https://doi.org/10.1501/Hukfak 0000001776.

Konyalı, İ. H. (1968). Abideleri ve kitâbeleri ile Kilis taribi. Fatih Matbaası.

Küçük, C. (1999). Osmanlı Devleti'nde millet sistemi. Osmanl Ansiklopedisi, (Cilt IV, ss. 208- 216) Yeni Türkiye Yayınları.

Sezen, T. (2006). Osmanlı yer adlanı (alfabetik sırayla). Başbakanlık Devlet Arşivleri Genel Müdürlüğ̈̈ Yayını. 
Taşkın, O. (2021). Ekonomik ve tipolojik bir tahlil: Kilis’te gayrimüslimler (1846-1849),

Mavi Atlas, 9(2), 167-181

McCarthy, J. (1998). Müslümanlar ve ą̧nlıklar. (Bilge Umar, Çev.) İnkılap Yayınevi.

Özel, A. (1996). Gayri Müslim. İçinde İslam Ansiklopedisi (Cilt 13, ss. 418-427). Türkiye Diyanet Vakfi Yayınları.

Pamuk, B. (2020). Kilis kazası (1867-1908). Kilis Belediyesi.

Zabun, S. (2018). 1833 y1l Sivas ili merkez kazası gayrimüslim nüfus defterlerine göre gayrimüslimlerin cizye vergisi ve konut mülkiyeti verileri ve fiziksel özellikleri. Uluslararası Ticaret ve Ekonomi Arastormalar Dergisi, 2(1), 51-67. https://doi.org/10.30711/utead.439049 